\title{
Reproductive success of Trypoxylon (Trypargilum) lactitarse (Hymenoptera: Crabronidae) in a fragmented landscape
}

\author{
Grayce Kelly Costa Oliveira', Marcos Antonio da Silva Elias² (D), \\ Leonardo Lima Bergamini ${ }^{3}$ @ \& Edivani Villaron Franceschinelli'
}

\author{
1.Universidade Federal de Goiás, Instituto de Ciências Biológicas, Av. Esperança, s/n, Campus Samambaia (Campus II), 74690-900 Goiânia, GO, Brasil. \\ (graycebio@gmail.com; edivanif@gmail.com) \\ 2. Secretaria de Estado da Educação de Goiás. Av. Anhanguera, n 1630, St Leste, Vila Nova, 74643-010 Goiânia, Go, Brasil. (marcos.jobbrt@gmail.com)
}

3. Centro de Estudos Ambientais do Cerrado, Reserva Ecológica do IBGE, DF-001, Km 38, 70312-970 Brasília, DF, Brasil. (Ilbergamini@gmail.com)

Received 23 December 2018

Accepted 13 February 2020

Published 06 March 2020

DOI 10.1590/1678-4766e2020004

\begin{abstract}
Fragmentation of natural vegetation often implies a reduction in local species richness and abundance. The resources used by bees and wasps for feeding and nesting are distributed quite irregularly in fragmented environments, which influences their foraging behavior, occurrence patterns and reproductive success. The objective of the present work was to determine if the size of native vegetation remnants influences the reproductive success of the solitary wasp species Trypoxylon (Trypargilum) lactitarse Saussure, 1867. Trap-nests were established along the edges of forest fragments of different sizes located in municipalities in the central region of the state of Goiás, Brazil. The nests were used to quantify nesting rate, number of cells with larvae, survival of larvae, proportion of nests attacked by parasitoids, and size of hatched adults. The foundation rate of trap-nests was greater in large fragments, whereas the mean number of cells per nest, parasitoidism rate, larval survival and sex ratios, and size of hatched adults did not differ between large and small fragments. Therefore, it appears that fragment size influences the survival or permanence of adults more so than it does that of the larvae in the studied fragments. There are two possible explanations for the difference in the foundation rate: 1) each female founds, in average, the same number of nests in small and large fragments, but the number of females is lower in the smaller fragments; 2) females have the capacity to provision several nests, but in the larger areas each female founds more nests than in smaller areas. However, it is necessary future studies to differentiate these two hypotheses.
\end{abstract}

KEYWORDS. Fragmentation, reproductive success, trap-nests.

RESUMO. Sucesso reprodutivo de Trypoxylon (Trypargilum) lactitarse (Hymenoptera: Crabronidae) em uma paisagem fragmentada. A fragmentação das vegetações nativas muitas vezes implica na redução da riqueza e abundância local de espécies. Nos ambientes fragmentados, os recursos para alimentação e nidificação de abelhas e vespas estão distribuídos de forma bastante irregular, influenciando no comportamento de forrageamento, padrão de ocorrência e no sucesso reprodutivo desses organismos. Dessa forma, o objetivo deste trabalho foi verificar se o tamanho das áreas de remanescentes de vegetação nativa interfere no sucesso reprodutivo de uma espécie de vespa solitária Trypoxylon (Trypargilum) lactitarse Saussure, 1867. Para tanto, estabelecemos ninhos armadilha nas bordas de fragmentos de mata de tamanhos diferentes localizados em munícipios da região central do estado de Goiás, Brasil. Estes ninhos foram utilizados como ferramenta de quantificação de taxa de nidificação, de número médio de células com larvas, sobrevivência destas larvas e tamanho dos adultos eclodidos. Neste trabalho, a taxa de fundação dos ninhos armadilhas foi maior nos fragmentos maiores. O número médio de células por ninhos, a taxa de sobrevivência das larvas, proporção de ninhos atacados por parasitoides, e o tamanho dos adultos eclodidos não diferiram entre as áreas grandes e pequenas. Existem duas explicações possíveis para a diferença na taxa de fundação: 1) cada fêmea funda, em média, o mesmo número de ninhos em fragmentos pequenos e grandes, mas o número de fêmeas é menor nos fragmentos menores; 2) as fêmeas têm a capacidade de prover vários ninhos, mas nas áreas maiores, cada fêmea funda mais ninhos do que em áreas menores. No entanto, são necessários estudos futuros para diferenciar essas duas hipóteses. É provável que o tamanho dos fragmentos possa estar influenciando mais na sobrevivência e na permanência dos adultos do que na das larvas.

PALAVRAS-CHAVE. Fragmentação, sucesso reprodutivo, ninhos armadilha.

Insects are under increasing pressure from anthropogenic factors, such as loss of natural habitat, ecosystem fragmentation and agricultural intensification (POTTS et al., 2006; BRITTAIN et al., 2010). These pressures can reduce the availability of resources used by insects for feeding and nesting (STEFFAN-DEWENTER \& TSCHARNTKE, 1999) and, consequently, reduce their reproductive success (WAJNBERG et al., 2012). As a consequence, anthropogenic factors, such as landscape fragmentation, are causing reductions in insect abundance and diversity (DiDHAm et al., 1996), and disrupting the ecological services they provide, such as pollination, which are important for the maintenance of plant diversity and the entire food chain of terrestrial ecosystems (PotTs et al., 2006).

Wasps have low effective population sizes and genetic diversity compared to other insects (LASALLE \& GAULD, 1993), which makes them more sensitive to environmental disturbances and prone to extinction, and thus bioindicators 
of environmental change (BEYER et al., 1987; TSCHARNTKE et al., 1998; Morato \& CAMpos, 2000). The wasp family Crabronidae comprises approximately nine thousand species (Pulawski, 2014). Adults are commonly found in flowers and are potential pollinators (BoHart MENKe, 1976). These wasps are solitary and predatory, supplying their nests with different species of spiders and insects. They construct their nests in dry soil, in dry or rotten trunks, in sand or mud, in other wasp's nests or in columns in houses (LOPES \& OLIVEIRA, 2004). Others are cleptoparasites, and do not build their own nests, laying their eggs in nests build by other wasps.

Studies have shown that the species richness and abundance of spiders are preserved in larger fragments and increase towards the interior (GoNÇALVES-SouZA et al., 2007). Wasp and bee diversity is known to be greater in continuous forests and larger fragments (MORATO \& CAMPOS, 2000), whereas their species composition differs between continuous areas and altered habitats. Some groups of wasps are more abundant in smaller fragments or open areas, while others are more abundant in continuous and better-preserved fragments (MORATO \& CAMPOS, 2000). The abundance of Trypoxylon figulus, for example, was found to be greater at edges than within forests in Switzerland (CoudRAIN et al., 2013).

Wasps of the genus Trypoxylon Latreille, 1796 (Hymenoptera: Cabronidae) are solitary, with nest construction and provisioning being done by females (Michener, 1974). Males and females of species of the subgenus Trypargilum are united (pairing) at the beginning of nest construction or soon after (CovILLE, 1982). The nests are constructed anew or made in pre-existing cavities. The walls of the nests are divided into rearing cells with clay, which are supplied with paralyzed spiders, mainly of the family Aranaeidae (Coville, 1982). Males defend the nest by chasing away predators and competing males, which also influences female reproductive success (BROCKMANN \& Grafen, 1989). As for most species of Hymenoptera, the sex of progeny is determined by whether the eggs are fertilized or not, with males developing from unfertilized eggs and females from fertilized eggs (PeruQuetti \& Del LAMA, 2003). In situations of low food availability or limited space for cell construction, females respond to selective pressures on sex ratio and produce more males, which are smaller and require fewer resources (O'NEILL, 2001; MORATO \& MARTINS, 2006).

Wasps of the genus Trypoxylon are easy to study because they successfully nest in trap-nests, which allow large sampling of their nests (CAMILLO \& BRESCOVIT, 1999). Nest-trapping allows important information to be obtained on the diversity and abundance of species in pre-existing cavities, and on their biology, including building materials used, nest architecture, and resources provided to larvae (GARÓFALO, 2000).

The present work investigated the reproductive success of Trypoxylon (Trypargilum) lactarse Saussure, 1867 , a common wasp along the edges of fragments of native vegetation. The main objective was to investigate whether the reproductive success of this wasp varied along the edges of fragments of different sizes. It was hypothesized that nesting rate, larval survival and hatched wasp size would decrease with fragment size since larger fragments have more extensive borders and thus should possess a greater amount of resources for the maintenance of adult wasps and for feeding larvae.

\section{MATERIAL AND METHODS}

Studied species. The wasp Trypoxylon lactitarse (Fig. 1) occurs from southern Canada to southern Argentina (Coville, 1981). Females select nesting sites and mate with a male early in its construction (GARCIA \& ADIs, 1995). Females construct the nest with a layer of clay and form six to eight cells with dividers (BuschINI et al., 2006). Trypoxylon lactitarse reproduces during the rainy season (CAMILLO et al., 1993). Trap-nests were installed during this period along the edges of nine forest fragments in the municipalities of Goianápolis, Leopoldo de Bulhões, Anápolis and Hidrolândia in the state of Goiás (Fig. 2).

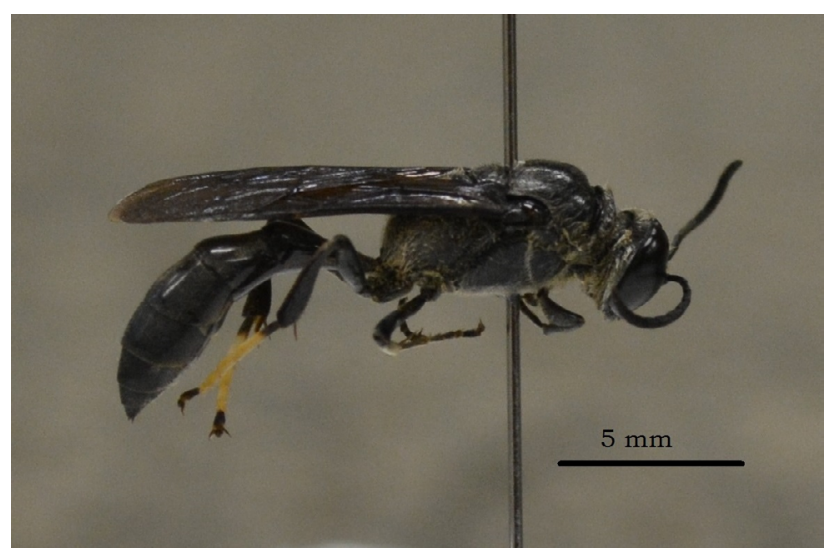

Fig. 1. Specimen of Trypoxylon (Trypargilum) lactitarse Saussure, 1867 (Hymenoptera: Crabronidae) captured in Goianápolis, state of Goiás, Brazil.

Trap-nests. Trap-nests were constructed using a 1-cm diameter and 10-cm deep cardboard tube with inlet holes facing the same side. The nests were mounted on wood pieces with longitudinally drilled holes, with 54 trap-nests in each piece. Trap-nests had a roof to prevent them from becoming wet during the rains (Fig. 3). These nest blocks were installed at a height of $1.5 \mathrm{~m}$ from the ground using stakes with the base of the stakes being smeared with grease or burned oil to prevent ants from accessing the nests. The nests were established along the edges of forest fragments of two study areas: five small fragments and one large fragment in the municipalities of Goianápolis, Leopoldo de Bulhões, Bonfinópolis, and Anápolis and four small fragments and one large fragment in the municipality of Hidrolândia. Two blocks of 54 nests (total 108 nests) were installed in each fragment, however some nests were lost in some fragments due to external inteferences (e.g. cattle knocking the traps, Tab.I).

The trap-nests were installed and monitored during the rainy season of 2013-2014, with intense nesting activity being observed between December and March. Nests were monitored biweekly for verification of nest construction and 


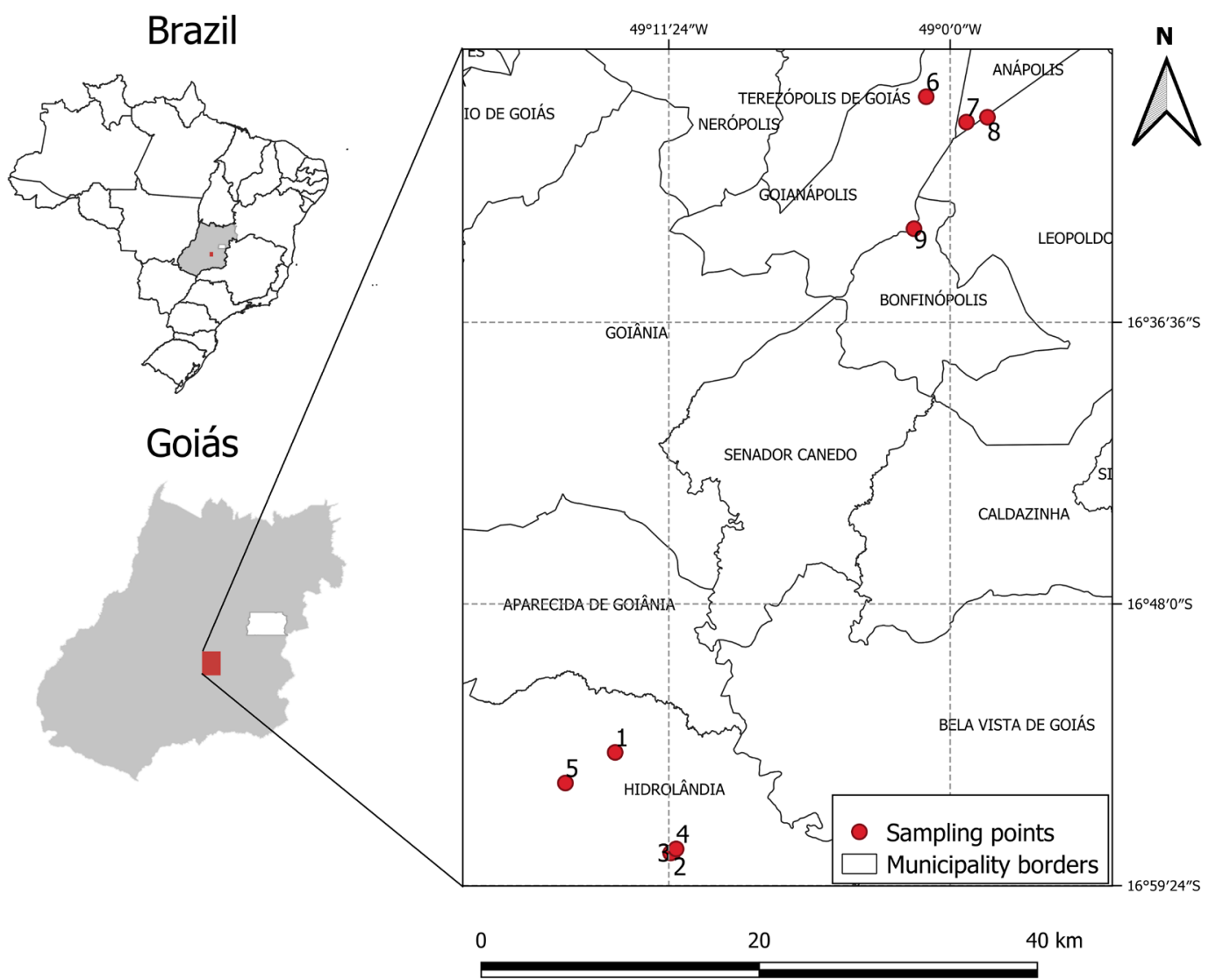

Fig. 2. Study areas in the municipalities of Goianápolis, Leopoldo de Bulhões, Bonfinópolis, Anápolis, and Hidrolânida, state of Goiás, Brazil.

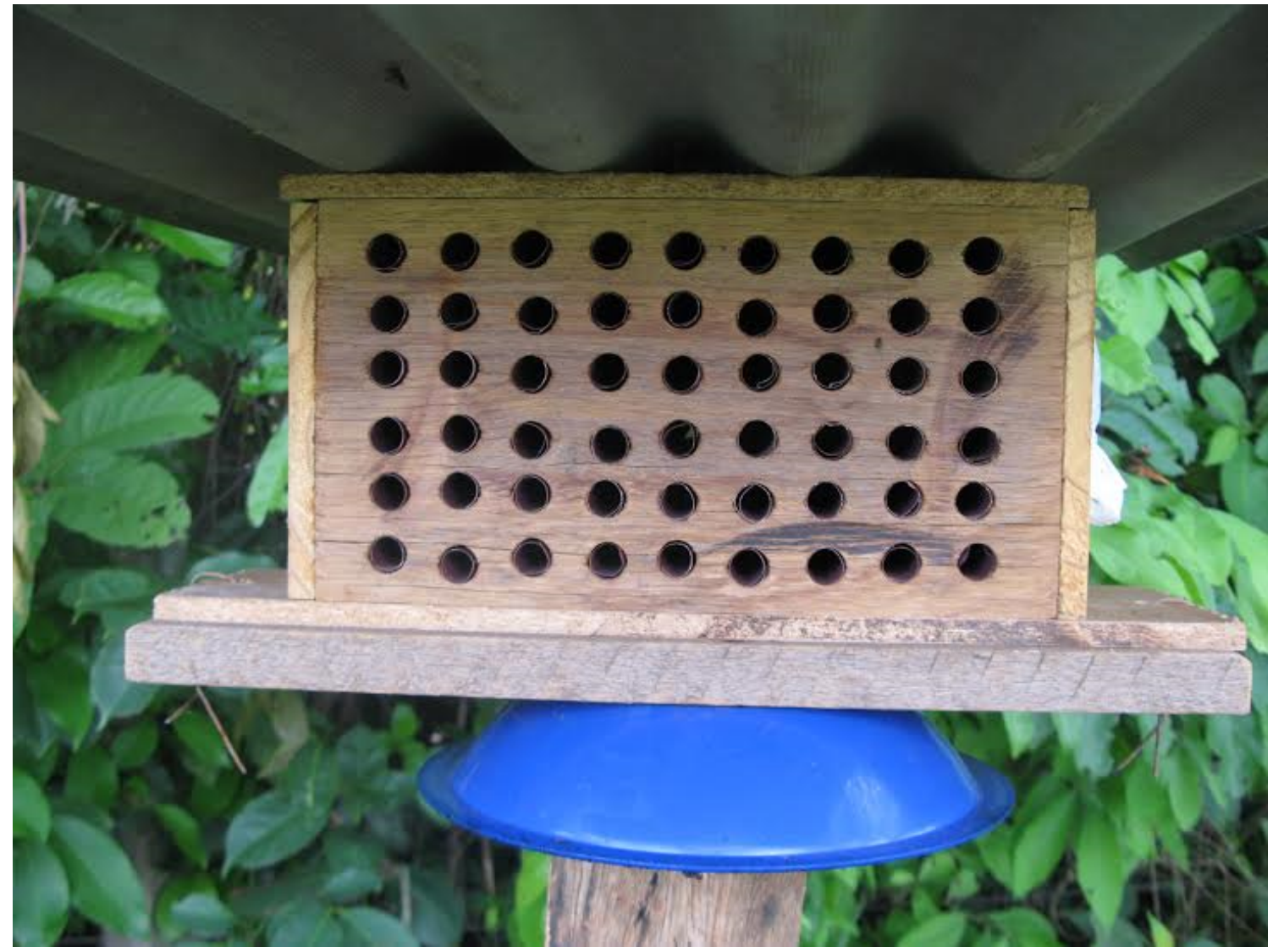

Fig. 3. Example of the trap-nest blocks installed in the study areas in the state of Goiás, Brazil. 
their collection. The number of occupied nests was counted during the period that the trap-nests were exposed at the forest edge (Tab. I). The nests were collected and taken to the Laboratório de Biologia Reprodutiva de Plantas of UFG, to await the development of larvae until emergence of adults. After adult emergence, the total number of live adults and dead larvae were counted to obtain the survival rate for each nest, we also recorded the presence of attacks by parasitoids. All emergent adults were identified by sex and had their intertegular distance measured to if there was a difference in its size between males and females and between fragments of different sizes. Vouchers were deposited in the pollinator collections of the Laboratório de Biologia Reprodutiva de Plantas of Universidade Federal de Goiás, Goiânia GO, Brazil.

Data analysis. The data were statistically analyzed by logistic regression, which is a model that uses binary values to designate, for example, true or false, success or failure, interferes or does not interfere. Since some trap nests were lost in some areas due to external interferences, the foundation rate was calculated by dividing the number of founded nests by an index of total exposure, defined as the product of the number of nests installed in each fragment and the number of days that the nests were made available. The effect of fragment size was tested by fitting a Generalized Linear Model - Binomial GLM (MccullaGH \& NelDER, 1989) — with the ratio between the number of nests founded and the availability index as the response variable and the $\log$ of fragment area as the predictor variable. The number of cells constructed per nest was analyzed to determine if there was an effect of fragment size on the average number of cells per fragment. A similar model was fitted to test differences in the rate of parasitoidism, with the proportion of nests attacked by parasitoids as the response variable.

Differences in survival rate of individuals between fragments of different sizes was tested using a Generalized Linear Mixed Model - Binomial GLMM (BoLKer et al., 2009) — with the ratio between the number of adults emerged from each nest and the number of cells constructed as the response variable and fragment size (categorized as small or large) as the predictor variable. Non-independence of nests from the same fragment was incorporated in the model by including the sampling fragment as a random variable.

A Linear Mixed Model LMM (BOLKER et al., 2009) was used to test whether the individuals emerging in larger fragments were larger than those emerging in smaller fragments with the intertegular distance of each individual as the response variable and fragment size category (small or large) as the predictor variable. Sex was included as a covariate to control for possible differences between the sexes. The nest of origin, nested by sampling fragment, was also included to control for non-independence of individuals from the same nest and from the same fragment.

The effect of fragment size on the sex ratio of each nest was estimated using a Generalized Linear Mixed Model with the ratio between the number of females and males by the total number of individuals in each nest as the response variable, and fragment size category as the predictor variable. Non-indenpendence of nests from the same fragment was incorporated in the model by including the sampling fragment as a random variable.

\section{RESULTS}

Trap-nests placed along the border of large fragments had more nests and occupied cells than those along the border of small fragments. The greatest number of adults was also found in one of the nests placed along the border of a large fragment. Six of the small fragments were noted to have no nesting. The results of the nest analyses are summarized in Tab. I.

A total of 155 wasps managed to reach the adult stage, of which only 135 (67 females, 68 males) were analyzed, while the remainders were not included in the analyses for various reasons. The data obtained in the present study verified greater nesting along the borders of large fragments than small fragments, which can be explained by the foundation rate increasing with increasing fragment area $(z=8.189, p<0.001 ;$ Fig. 4). No difference was found between small and large fragments for mean number of nest cells $(z=1.155, p=0.248$; Fig. 5), survival rate $(z=0.784$, $\mathrm{p}=0.433$; Fig. 6$)$, and parasitoidism rate $(\mathrm{z}=0.394, \mathrm{p}=$ 0.694; Fig. 7).

Tab. I. Number of trap nests installed and founded by Trypoxylon (Trypargilum) lactitarse Saussure, 1867 (Hymenoptera: Crabronidae), number of days with nests available, number of cells with wasps, and adults hatched per study area, state of Goiás, Brazil.

\begin{tabular}{|c|c|c|c|c|c|c|c|}
\hline Area & Size & Hectares & No. of traps & No. of days & No. of nests & No. of cells & No. of adults \\
\hline 1 & large & 1600 & 54 & 124 & 15 & 52 & 22 \\
\hline 2 & small & 9.71 & 108 & 66 & 4 & 14 & 4 \\
\hline 3 & small & 54 & 108 & 74 & 8 & 33 & 27 \\
\hline 4 & large & 517.61 & 108 & 204 & 65 & 199 & 102 \\
\hline 5 & small & 2.52 & 108 & 151 & 0 & 0 & 0 \\
\hline 6 & small & 55.35 & 108 & 127 & 0 & 0 & 0 \\
\hline 7 & small & 25 & 108 & 14 & 0 & 0 & 0 \\
\hline 8 & small & 0.1 & 54 & 94 & 0 & 0 & 0 \\
\hline \multirow[t]{2}{*}{9} & small & 1.8 & 54 & 74 & 0 & 0 & 0 \\
\hline & & Total & 1,080 & & 92 & 298 & 155 \\
\hline
\end{tabular}


Fragment size (large or small) was found to have no influence on the size of hatched wasps $(\mathrm{z}=-0.741, \mathrm{p}=$ 0.982; Fig.8). Male wasps were, in general, smaller than

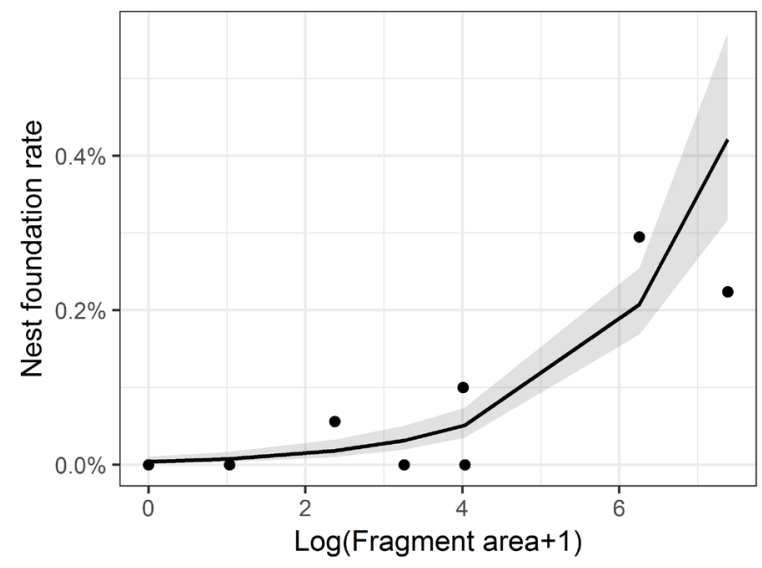

Fig. 4. Results of the Generalized Linear Model (GLM) between the nests foundation rate and the log of fragment area. The foundation rate increasing with increasing fragment area $(z=8.189, p<0.001)$.

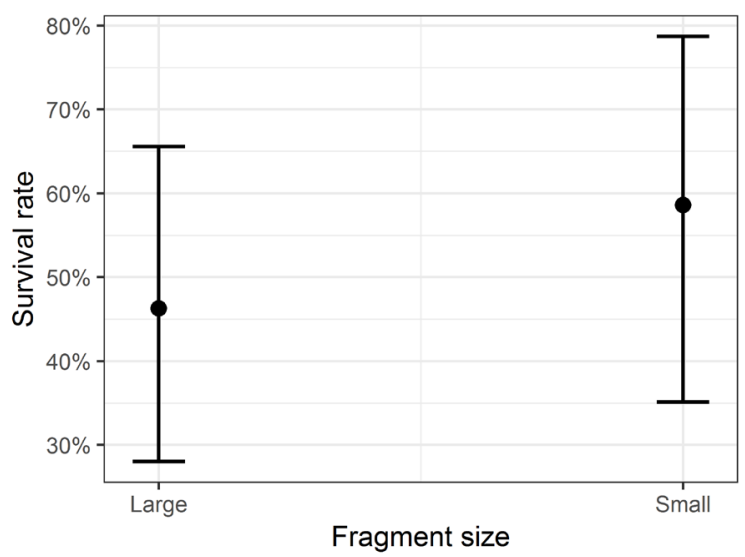

Fig. 6. Results of the Generalized Linear Mixed Model (GLMM) between the numbers of adults emerged from each nest and fragment size. No difference was found between small and large fragments for survival rate $(\mathrm{z}=0.784, \mathrm{p}=0.433)$.

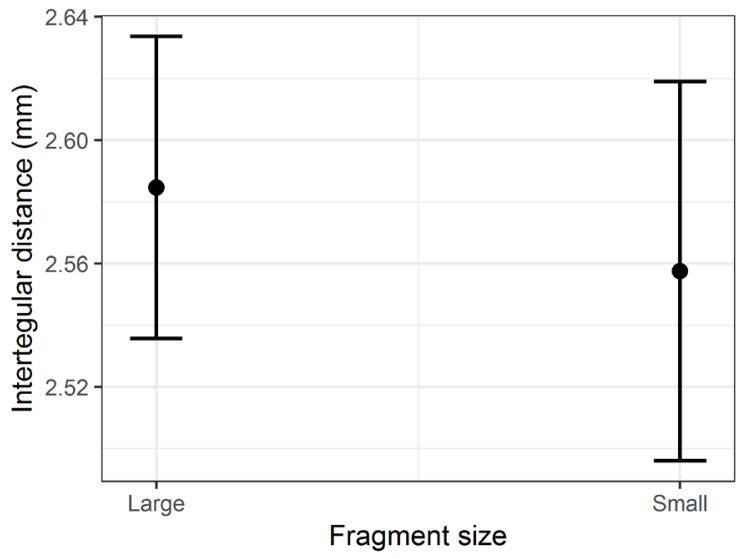

Fig. 8. Results of the Linear Mixed Model (LMM) between the intergular length of each individual and fragment size category. Fragment size was found to have no influence on the size of hatched wasps $(z=-0.741, p=$ $0.982)$. female wasps $(\mathrm{t}=-3.693, \mathrm{p}<0.001)$. Despite a tendency for a biased sex ratio in favor females in small areas, the difference was not significant (Fig. 9) $(z=1.224, \mathrm{p}=0.221)$.

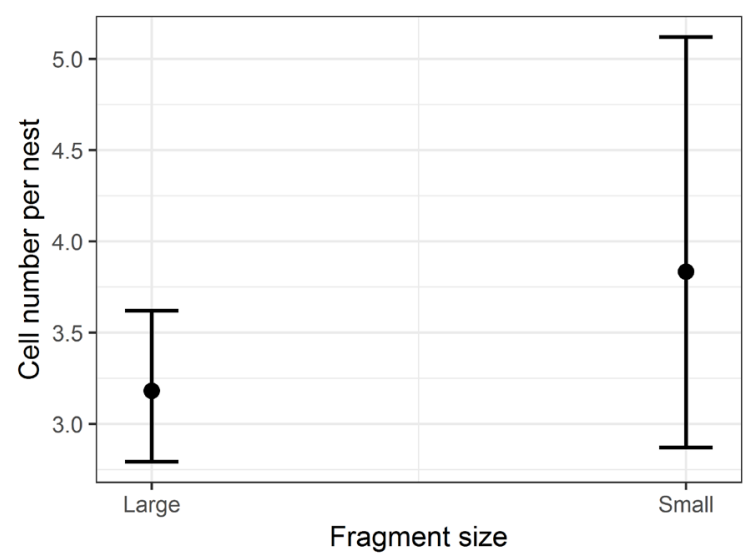

Fig. 5. Results of the Generalized Linear Model (GLM) between fragment size and the average number of cells per fragment. No difference was found between small and large fragments for mean number of nest cells $(\mathrm{z}=1.155, \mathrm{p}=0.248)$.

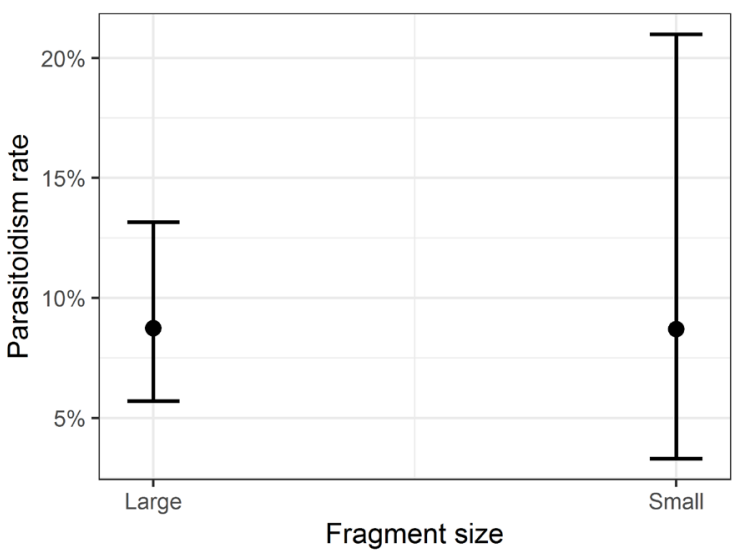

Fig. 7. Results of the Generalized Linear Mixed Model (GLMM) between parasitoidism rate (proportion of nests attacked by parasitoids) and fragment size. No difference was found between small and large fragments for parasitoidism rate $(\mathrm{z}=0.394, \mathrm{p}=0.694)$.

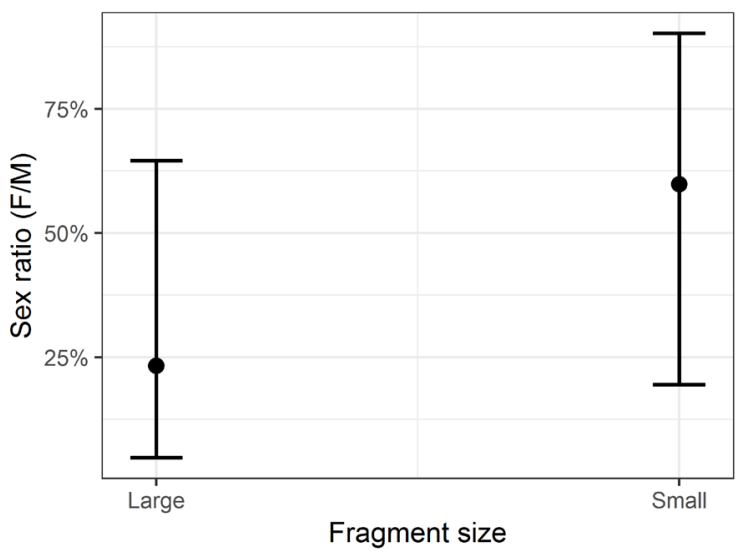

Fig. 9. Results of the Generalized Linear Mixed Model (GLMM) between sex ratios and fragment size category. Despite a tendency for a biased sex ratio in favor females in small areas, the difference was not significant $(z$ $=1.224, \mathrm{p}=0.221$ ). 


\section{DISCUSSION}

The results of the present study showed that nesting occurred with greater intensity along the borders of the large fragments; that is, more nests were founded in larger than smaller fragments. In several smaller fragments, no nesting was found. Other works have reported different results. For example, in the Amazon Region, Trypoxylon lactitarse and $T$. nitidum preferentially established their nests in smaller forest fragments (MORATO \& CAMPOS, 2000). In the state of São Paulo, high nesting of species of Trypoxylon (Trypargilum) Kohl was observed in disturbed areas of the Cerrado that had abandoned houses and orchards surrounded by crops and pastures (CAMILlo et al., 1994; SANTONI et al., 2009). Apparently, wasps of the genus Trypoxylon easily adapt to disturbed environments (CAMILLO et al., 1994). It is possible that the fragments of the present study were smaller and more isolated than those of the previous studies, and thus did not provide sufficient resources for the maintenance of populations of $T$. lactitarse.

TSCHARNTKE et al. (1998) observed that wasps and bees are very sensitive to environmental disturbances and can be used as bioindicators of habitat quality. These authors showed that wasp diversity increases with the quality of the habitat. It is possible that the quality habitat required for the occurrence of $T$. lactitarse in the study areas with resources for feeding adults (e.g., floral nectar) and larvae (mainly spiders), and the availability of nesting sites and nest building materials - is easier found in the larger fragments (RoubiK, 1989; GATHMANN \& TsCHARNTKE, 2002; TSCHARNTKE et al., 2002)

The present work showed that only the foundation rate of trap-nests is higher in larger fragments. Mean number of cells per nest, larval survival rate, parasitoidism rate, and size of hatched adults did not differ between large and small fragments. These findings demonstrate that fragment size has a greater impact on adult permanence and nesting activity than on the measures of their success of immatures. Probably, larger fragments possess greater amounts and diversity of feeding resources for the adults of these wasp species. Adult wasps of the genus Trypoxylum feed mainly on nectar, and smaller fragments of native vegetation are likely to possess less abundant and diverse floras of flowering plants (TABARelli et al., 1999; BeníteZ-Malvido \& MartínezRAMOS, 2003) that provide resources for floral visitors (AIZEN \& FeINSINGER, 1994; DonaldSON et al., 2002). The present study was carried out during the rainy season, which is the period with the greatest flower production by herbaceous plants in the Cerrado of the Center-West Region of Brazil (BATALHA \& Martins, 2004). Herbaceous plants are quite common along the borders of forest and Cerrado fragments (SOARES et al., 2015); however, trees bloom mainly during the dry or pre-rainy period (BATALHA \& MARTINS, 2004; OliveIRA $\&$ GibBS, 2000). Thus, the flowering of a few species and plants may not be enough to maintain adults in the small fragments, especially because the matrix surrounding those fragments is composed of pasture with few occurences of nectar-providing plants.

Nesting also depends on availability of resources for nest building and food provisioning for the larvae. The larvae of T. lactitarse feed on spiders (BuschINI, 2007). The abundance and diversity of spiders available to feed larvae should occur in areas where habitat quality is highest. The quality of the environment can act on the abundance and richness of spiders since they are also sensitive to several ecological factors such as fragmentation and habitat loss (RusHTON et al., 1987). Larger fragments should offer more food for spiders and support sites for the installation of their webs. Studies have shown that the species richness and abundance of spiders are preserved in larger fragments and increase towards the interior (GoNÇALVEZ-SouZA et al., 2007).

Most spiders are sensitive to abiotic factors such as luminosity, temperature and biotics, such as the amount of food resources and vegetation size, because they feed mainly on insects, which are also sensitive to these ecological factors (WISE, 1993; FoELIX, 1996). Therefore, it can be inferred that the results of the present study may also be related to the sensitivity of spiders to fragmentation since nest foundation was greater in large areas, probably due to the greater availability of resources for larvae.

Wasp size and survival did not differ with fragment size. The same pattern was previously reported for maximum head width (CAMILlo \& BresCovit, 1999). Thus, it seems that the difference in resources between the small and large fragments was compensated for by a smaller number of nests being occupied by females, thereby maintaining an adequate quantity of food for each larva and preventing reductions in their survival and development. BuschINI et al. (2006) observed that nests with larger diameters, as used in our experiment, had higher survival rates for $T$. lactitarse larvae. Nesting space is another factor that has been attributed to the survival of wasp larvae (BERTON et al., 2009). In addition, the survival of wasp larvae may be influenced by the intensity of infestation by pathogens and by climatic conditions (Morato \& CAMPos, 2000). Nevertheless, we found no difference between the parasitism rate of small and large fragments.

Fragment size was found to have no influence on the sex ratio of hatched wasps. Previous studies have found that Trypoxylon lactitarse wasps may exhibited a biased sex ratio in favor of females or males (BUSCHINI, 2007). Some authors have suggested that the sex ratio biases depending on the diameter of the trap-nest occupied (PeruQuetti \& Del Lama, 2003; Buschini, 2007). Since females are able to manipulate the sex of their offspring, nests in small spaces are usually intended for the production of males (CAMILLO et al., 1993; Coville \& Coville, 1980), which are smaller and require fewer resources for their development. In situations where nesting space is not limited, offspring of both sexes are produced (Peruquetti \& Del Lama, 2003). Wooden trap-nests of $1 \mathrm{~cm}$ in diameter and $10 \mathrm{~cm}$ in depth were used 
in this study allow the establishment of both female and male larvae. Smaller diameters may limit the food supply for larvae, which leads to a greater occurrence of males (BUSCHINI, 2007). However, some authors suggest that other factors may act on the sex ratio, such as the availability of resources for feeding the larvae and the loss of cells due to attacks by parasites (Aguiar \& GARóFALO, 2004). Following this argument, the observed sex ratio of $1: 1$ taken together with the similar number of cells per nest, would be an evidence of no resource limitation at the individual nest level. In T. lactitarse the 1: 1 ratio between males and females can be partly explained by the guarding behavior of the male during the foundation of the nest, since each male is directly involved in the foundation of only one nest at a time. The male allows the female to devote more time to foraging and to accumulate more prey in each cell (BUSCHINI, 2007)

There has been little research on the effects of fragmentation of native vegetation on the biology of solitary wasps. In the present study, fragment size was only related to the rate of nest foundation. The other parameters analyzed, such as average number of cells per nest, size of hatched wasps, parasitoidism rate, larval survival and sex ratios did not vary with size of the sampled fragment. Therefore, it appears that fragment size influences the survival or permanence of adults more so than it does that of the larvae in the studied fragments. There are two possible explanations for the difference in the foundation rate: 1) each female founds, in average, the same number of nests in small and large fragments, but the number of females is lower in the smaller fragments; 2 ) females have the capacity to provision several nests, but in the larger areas each female founds more nests than in smaller areas.

However, future studies are necessary to differentiate these two hypotheses. It is also important to investigate aspects that are not only related to the reproductive biology of the species, such as the behavioral aspects of habitat the choice by solitary wasps in fragmented landscapes.

Acknowledgments. We would like to thank all the farmers who permitted access to their properties. The Conselho Nacional de Desenvolvimento Científico e Tecnológico - CNPq, Food and Agriculture Organization (FAO), Fundo Brasileiro para a Biodiversidade (FUNBIO), and the Ministério do Meio Ambiente (MMA) provided funding for this study. Marcos A. Elias was supported by a CNPq scholarship. Leonardo L.Bergamini and G.K. C. Oliveira were supported by a CAPES scholarship.

\section{REFERENCES}

Aguiar, C. M. \& Garófalo, C. A. 2004. Nesting biology of Centris (Hemisiella) tarsata Smith (Hymenoptera, Apidae, Centridini). Revista Brasileira de Zoologia 21:477-486.

Aizen, M. A. \& Feinsinger, P. 1994. Habitat fragmentation, native insect pollinators, and feral honeybees in Argentine 'Chaco serrano'. Ecological Applications 4:378-392.

Batalha, M. A. \& Martins, F. R. 2004. Reproductive phenology of the Cerrado community in Ema National Park (Central Brazil). Australian Journal of Botany 52:149-161.

Benítez-Malvido, J. \& Martínez-Ramos, M. 2003. Impact of Forest Fragmentation on Understory Plant Species Richness in Amazonia. Conservation Biology 17:389-400. doi:10.1046/j.15231739.2003.01120.x
Berton, L.; Castanho, M. J. P. \& Buschini, M. L. T. 2009. Abordagem Fuzzy na Taxa de Sobrevivência de Trypoxylon (Trypargilum) lactitarse (Hymenoptera: Crabronidae). Ambiência 5(3):419-431.

Beyer, W. N.; Miller, G. W. \& Fleming, W. J. 1987. Populations of trap-nests wasps near a major source of fluoride emissions in Western Tennessee. Proceedings of the Entomological Society of Washington 89(3):478-482.

Bohart, R, M. \& Menke, A. S. 1976. Sphecidae wasps of the world - a generic revision. Berkeley, University of California Press. 695p.

Bolker, B. M.; Brooks, M. E.; Clark, C. J.; Geange, S.W.; Poulsen, J. R.; Stevens, M. H. H. \& White, J. S. S. 2009. Generalized linear mixed models: a practical guide for ecology and evolution. Trends in Ecology \& Evolution 24:127-135.

Brittain, C. A.; Vighi, M.; Bommarco, R.; Settele, J. \& Potts, S.G. 2010. Impacts of a pesticide on pollinator species richness at different spatial scales. Basic and Applied Ecology 1:106-115.

Brockmann, H. J. \& Grafen, A. 1989. Mate conflict and male behaviour in a solitary wasp, Trypoxylon (Trypargilum) politum (Hymenoptera: Sphecidae). Animal Behavior 37:232-255.

Buschini, M. L. T. 2007. Life-history and sex allocation in Trypoxylon (syn. Trypargilum) lactitarse (Hymenoptera: Crabonidae). Journal of Zoological Systematics and Evolutionary Research 45:206-213.

Buschini, M. L. T.; Niesing, F. \& WolfF, L. L. 2006. Nesting biology of Trypoxylon (Trypargilum) lactitarse Saussure (Hymenoptera: Crabronidae) in trap-nests in Southern Brazil. Brazilian Journal of Biology 66(3):919-929.

Camillo, E. \& Brescovit, A. D. 1999. Aspectos biológicos de Trypoxylon (Trypargilum) lactitarse Saussure e Trypoxylon (Trypargilum) rogenhoferi Kohl (Hymenoptera: Sphecidae) em ninhos-armadilhas, com especial referência a suas presas. Anais da Sociedade Entomológica do Brasil 28(2):251-261.

Camillo, E.; Garófalo, C. A.; Muccillo, G. \& Serrano, J. C. 1993. Biological observations on Trypoxylon (Trypargilum) lactitarse Saussure in southeastern Brazil (Hymenoptera: Sphecidae). Revista Brasileira de Entomologia 37:769-778.

Camillo, E.; Garófalo, C. A. \& Serrano, J. C. 1994. Observações sobre a biologia de Trypoxylon (Trypargilum) rogenhoferi Kohl (Hymenoptera: Sphecidae). Anais da Sociedade Entomológica do Brasil 23(2):299310.

Coudrain, V.; Herzog, F. \& Entling, M. H. 2013. Effects of habitat fragmentation on abundance, larval food and parasitism of a spiderhunting wasp. PLoS ONE 8:e59286. doi: 10.1371/journal.pone.0059286

Coville, R. E. 1981. Biological observations on three Trypoxylon wasps in the subgenus Trypargilum from Costa Rica: T. nitidum schulthessi, T. saussurei and T. lactitarse (Hymenoptera: Sphecidae). The PanPacific Entomologist 57:332-340.

COVILLE, R. E. 1982. Wasps of the genus Trypoxylon sugenus Trypargilum in the North America. Berkeley, University of California Press, v. 97. $147 \mathrm{p}$.

Coville, R. E. \& Coville, P. L. 1980. Nesting biology and male behavior of Trypargilum tecnoctitlan in Costa Rica (Hymenoptera: Sphecidae). Annals of the Entomological Society of America 73:110-119.

Didham, R. K.; Ghazoul, J.; Stork, N. E. \& Davis, A. J. 1996. Insects in fragmented forests: a functional approach. Trends in Ecology \& Evolution 11:255-260.

Donaldson, J.; NÄNnI, I.; Zachariades, C. \& Kemper, J. 2002. Effects of Habitat Fragmentation on Pollinator Diversity and Plant Reproductive Success in Renosterveld Shrublands of South Africa. Conservation Biology 16:1267-1276. doi:10.1046/j.1523-1739.2002.99515.x

Foelix, R. F. 1996. Biology of Spiders. 2ed. New York, Oxford, Oxford University Press. 330p.

Garcia, M. V. B. \& AdIs, J. 1995. Comportamento de nidificação de Trypoxylon (Trypargilum) rogenhoferi Kohl (Hymenoptera: Sphecidae) em uma floresta inundável de várzea na Amazônia Central. Amazoniana 13:259-282.

Garófalo, C. A. 2000. Comunidade de abelhas (Hymenoptera, Apoidea) que utilizam ninhos-armadilha em fragmentos de matas do Estado de São Paulo. Anais do Encontro sobre Abelhas-Ribeirão Preto, SP 4:121-128.

Gathmann, A. \& TscharntKe, T. 2002. Foraging ranges of solitary bees. Journal of Animal Ecology 71:757-764. 
Gonçalves-Souza, T.; Tobon, G. M. \& Brescovit, A. D. 2007. Effects of habitat fragmentation on the spider community (Arachnida, Araneae) in three Atlantic forest remnants in Southeastern Brazil. Revista Ibérica de Aracnologia 16:35-42.

LASAlle, J. \& GAUld, I. D. 1993. Hymenoptera: their diversity, and their impact on the diversity of other organisms. In: LASALLE, J. \& GAULD, I. D. eds. Hymenoptera and biodiversity. Wallingford, CAB International, p. 1-26.

Lopes, S. M. \& Oliveira, E. H. 2004. Três espécies novas do gênero Chorisoneura (Blattellidae, Chorisoneuriinae) coletadas em ninhos de Sphecidae (Hymenoptera) do Estado do Acre, Brasil. Iheringia, Série Zoologia 94:375-380. doi:https://dx.doi.org/10.1590/S007347212004000400004

McCullagh, P. \& Nelder, J. A. 1989. Generalized linear models. 2ed. London, Chapman and Hall. 532p.

Morato, E. F. \& CAmpos, L. A. O. 2000. Efeitos da fragmentação florestal sobre vespas e abelhas solitárias em uma área da Amazônia Central. Revista Brasileira de Zoologia 17(2):429-444.

Morato, E. F. \& Martins, R. P. 2006. An overview of proximate factors affecting the nesting behavior of solitary wasps and bees (Hymenoptera: Aculeata) in preexisting cavities in wood. Neotropical Entomology 35(3):285-298.

Oliveira, P. E. \& GiBBS, P. E. 2000. Reproductive biology of woody plants in a cerrado community of Central Brazil. Flora 195:311-329.

O’NeILl, K. M. 2001. Solitary wasps: Behavior and natural history. Ithaca, Cornell University Press. 406p.

Peruquetti, R. C. \& Del Lama, M. A. 2003. Alocação sexual e seleção sexo-dependente para tamanho de corpo em Trypoxylon rogenhoferi Kohl (Hymenoptera: Sphecidae). Revista Brasileira de Entomologia 47:581-588.

Potts, S. G.; Petanidou, T.; Roberts, S.; O’toole, C.; Hulbert, A. \& WILMER, P. 2006. Plant-pollinator biodiversity and pollination services in a complex Mediterranean landscape. Biological Conservation 129:519-529.

Pulawski, W. J. 2014. Catalog of Sphecidae sensu lato. Available at $<$ http://www.calacademy.rg/research/entology/Entomology_Resources/
Hymenoptera/sphecidae/Genera_and_species_PDF/introduction.htm>. Accessed on 17 June 2016.

RoubiK, D. W. 1989. Ecology and natural history of tropical bees. New York, Cambridge University Press. 514p.

Rushton, S. P.; ToPPING, C. J. \& EYRE, M. D. 1987. The habitat preferences of grassland spiders as identified using detrended correspondence analysis (Decorama). Bulletin of British Arachnological Society 7:165-170

Santoni, M. M.; Brescovit, A. D. \& Lama, M. A. 2009. Ocupação diferencial do habitat por vespas do gênero Trypoxylon (Trypargilum) Latreille (Hymenoptera, Crabronidae). Revista Brasileira de Entomologia 53(1):107-114. doi:https://dx.doi.org/10.1590/S008556262009000100024

Schowalter T. D. 2016 Insect Ecology: An Ecosystem Approach. 4ed. Amsterdam, Academic Press, Elsevier. 774p.

Soares N. S.; Gonçalves C. A.; AraúJo G. M. \& Lomônaco, C. 2015. Floristic composition and abundance in forest fragments: a case study from Southern Goiás. Brazilian Bioscience Journal 31:1238-1252.

SteFFAn-Dewenter, I. \& TsChARnTKE, T. 1999. Effects of habitat isolation on pollinator communities and seed set. Oecologia 121:432-440.

Tabarelli, M.; Mantovani, W. \& Peres, C. A. 1999. Effects of habitat fragmentation on plant guild structure in the montane Atlantic forest of southeastern Brazil. Biological Conservation 91:119-127.

Tscharntke, T.; Gathmann, A. \& StefFan-dewenter, I. 1998. Bioindication using trap-nesting bees and wasps and their natural enemies: community structure and interactions. Journal of Applied Ecology 35:708-719.

Tscharntke, T.; Steffan-dewenter, I.; Kruess, A. \& Thies, C. 2002. Contribution of small habitat fragments to conservation of insect communities on grassland cropland landscapes. Ecology Application 12:354-363.

Wajnberg, E.; Coquillard, P.; Vet, L. E. M. \& Hoffmeister, T. 2012. Optimal Resource Allocation to Survival and Reproduction in Parasitic Wasps Foraging in Fragmented Habitats. PLoS ONE 7(6):e38227. doi:https://doi.org/10.1371/journal.pone.0038227

Wise, D. H. 1993. Spiders in ecological webs. New York, Cambridge University Press. 328p. 